\title{
Approaches for Poverty Alleviation and Sustainable Development in Nigeria: A Study of Ebonyi State Community Based Poverty Reduction Agency (EB-CPRA)
}

\author{
Nkwede Joseph O. \\ Department Of Political Science, Ebonyi State University, Abakal1ki \\ E-mail: senatorlife2011@yahoo.com
}

Received: October 22, 2013 Accepted: November 9, 2013 Available online: December 11, 2013

doi:10.11114/ijsss.v2i1.249 URL: http://dx.doi.org/10.11114/ijsss.v2i1.249

\begin{abstract}
Globally, poverty is an issue that has generated a lot of concerns to both the government, private individuals and non-governmental organizations. In Nigeria, the alarming growth rate of poverty and its effects on the teeming populace is quite de-humanizing. Successive government in Nigeria initiated several policy options geared toward reducing poverty scourge in the country, but such efforts have not yielded the desired result, particularly as the poverty rate is rising astronomically in the country. It is against this back drop that this paper therefore examines the activities of Ebonyi State Community Based Poverty Reduction programme with a view to ascertaining its contributions in the crusade and fight against poverty in Ebonyi State. While adopting review and trends analytical approach, the study revealed that EB-CPRA has to a large extent impacted positively well on the socio-economic lives of the citizenry living below poverty level in the state through several community projects. The paper submits that a lot still need to be done since perennial problem of poverty in Nigeria has not be adequately addressed. Consequently, it recommends among other things, involvement of the rural people in the selection of EB-CPRA projects in the rural communities as the best approach for poverty reduction in Nigeria.
\end{abstract}

Keywords: Approach, Poverty Alleviation, Sustainable Development, Nigeria

\section{Introduction}

Poverty worldwide has become an issue of serious concern especially in third world states of Africa, Asia and Latin America. In Nigeria, poverty chart indicates that seventy percent out of the country's population of over one hundred and forty million people are extremely poor (Obedan, 2006). Obviously, the poor masses reside predominantly in the rural settings, which incidentally is one of the major reasons for rural-urban migration in Nigeria. It is not in doubt that the exodus of youths from the rural to urban areas in search of white-Collar jobs has many implications on the development and administration of metropolitan government. Such implication for rural-urban migrations include: frustrations in search of non-existing white collar jobs, over stretching of public infrastructures and high rate of social vices.

Paradoxically, the issue of poverty had been in existence since the evolution of Nigeria as a nation. Report of the federal office of statistics 1999 showed that between late 70's and early 90's, the poverty level in Nigeria stood at 27 percent, but subsequently jumped to 46 percent as at 1996 when most countries within the poverty bracket were moving toward complete eradication of poverty in their respective states (Osagie, 2007). Certain factors were responsible for the astronomical rise in the poverty level in Nigeria. Such factors include: gross mismanagement of the countries scarce resources by our corrupt and dishonest leaders; long military leadership in the country; abandonment of agriculture for oil economy and unstable economy (Eminue, 2005 \& Igbuzor, 2006).

Apparently, successive administrations in the country have at various times initiated some programmes aimed at addressing poverty problems and its concomitant effects on Nigerian State. The military regime of Gen Olusegun Obasanjo initiated operation feed the nation programme. Under Shehu Shagari regime (1979-1983), the administration introduced the policy of "Green revolution" aimed at encouraging Nigerians to develop 
interest on reviving agricultural sector as a strategy for reducing poverty in the country. The Babangida military regime (1985-1993) introduced the Directorate for Food, Roads and Rural Infrastructure (DFRRI) and the pet project of her wife called better Life for Rural women. Again, the military regime of Late Gen. Sanni Abacha launched the Family Economic Advancement programme (FEAP) with the utmost intension of fighting poverty nationwide. Most of these programmes by their contents were very laudable, but their implementation strategies were window dressing and cosmetic in nature, especially as their impacts did not reduce the level of poverty in the country.

Chief Olusegun Obasanjo after assumption of office as a civilian president of the Federal Republic of Nigeria in May, $29^{\text {th }} 1999$, instituted Poverty Alleviation Programme (PAP) by the year 2000. Unfortunately the policy package did little or nothing to address poverty problems in Nigeria. Consequently, the programme was re-organised and renamed poverty Eradication programme (PEP). Nomenclatures not withstanding, the rural populace who were supposed to be the target beneficiaries of these programmes never knew of the existence of such initiatives, not to talk of their implementations.

Against the backdrop of failed government programmes to address the ravaging problems of poverty in Nigeria, the emerging governance considered it necessary to come up with community based poverty reduction strategy as a panacea to the menace of poverty, since the majority of the poor populace live in the rural areas. This of course gave rise to the constitution of presidential panel to package and streamline all the poverty related programmes and agencies of the government. That arrangement prompted the production of a document on Community Action programme for poverty Alleviation (CAPPA). In line with the above strides to reduce poverty rate in Nigeria, Ebonyi State Government in the year 2005 established Ebonyi State Community Based Poverty Reduction Agency (EBCPRA) with the objective to tackle rural poverty.

Essentially, the objectives of this paper are as follows:

- To ascertain the various approaches for reduction/alleviation of poverty in Nigeria.

- To examine the causes of and problems of poverty in Nigeria, particularly Ebonyi State.

- To suggest strategies and ways of reducing poverty for overall social progress and national development.

\section{Delineation of Concepts}

\subsection{Poverty}

Poverty like any other concept in social science discipline lack precise and universally accepted definition. The nature and 'degree of poverty, its comprehension differs from one society to another.

Ezeanyika (2004) defined poverty as the absence or lack of basic entitlements which could be economic, political or socio-cultural in nature. A critical analysis of this definition indicates that poverty emerges as a result of lack of financial, human and physical necessities capable of creating suitable environment for sustainable living standard. Chambers (1995) saw poverty as a subset of the general condition of deprivation whose dimension include: social inferiority, isolation, physical weakness, vulnerability, powerlessness and humiliation.

World Bank Development Report (1992) described poverty as the inability to attain a minimum standard of living. World Bank (1999) report aptly defined poverty as a state where an individual is not able to cater adequately for his/her basic needs of food, clothing and shelters; he or she is unable to meet social and economic obligations; lacks gainful employment, skills, assets and self-esteem; has limited access to social and economic infrastructure such as education, health, portable water and sanitation; and consequently has limited chance of advancing his/her welfare to the limit of his/her capacities.

In the words of Eminue (2005) and Landis (1980) Poverty is a state where an individual is not able to cater adequately for his or her basic need of food, clothing and shelter, is unable to meet social and economic obligation; lacks gainful employment, skills, assets and self esteem; and has limited access to social and economic infrastructure such as education, health , potable water and sanitation; and consequently, has limited chance of advancing his/her welfare to the limit of his/her capacities.

Corroborating the above, Ravillion and Chon (2004) see poverty as lack of command over basic consumption leading to insufficient food, clothing and shelter. It could be this that made Dike (2002) to conceptualize poverty as existing when the resources of families or individuals are inadequate to provide a socially acceptable standard of living. Contemporaneously, poverty can safely be looked upon as a situation of people living below a specific minimum level of "income", and in imaginary poverty line that recognizes neither national boundaries nor levels of national per capital income (Nkwede, 2011 and Todaro, 1992). 
Obadan (1996) poverty refers to lack of physical necessities, assets and income; a condition which results in deprivation, social inferiority, isolation, physical wideness, vulnerability, powerlessness and humiliation. According to Obi et al (2008:170) poverty is a reflection of some glaring defects in a state and its economy which normally manifest in the form of mass penury, mass unemployment, poor welfare services, lack of basic necessities of food, clothing and shelter, social inferiority, disempowerment, deprivation, isolation, humiliation, vulnerability to ill-health, drought, economic decline, crime and other societal conflicts.

In Nigeria, the vulnerability to poverty and its indices are mostly found in the rural areas and marginal urban zones where basic infrastructural facilities are lacking. In the same vein, the poor are gripped with depression, degradation, deprivation, insecurity, poor savings ability, poor dietary, shelter and haggard clothing and use of crude farm implements in their farm works. Apart from these, they are vulnerable to disaster, ill-treatment by the institutions of the state. They are rather powerless to influence public decisions affecting their lives.

\subsection{Poverty Reduction}

Poverty reduction and poverty alleviation will be used interchangeably in this paper. Poverty reduction is generally considered to be a means through which an individual, community or country is relieved of the hardships resulting from poverty and provide basic necessities of life for good living/higher standard of living. Poverty alleviation is designed to tackle the institutional web of poor masses in the society.

African Development Bank (1998) posits that poverty alleviation can only be realized through sustained and broad-based economic growth complemented by efficient provision of social services such as education, health-care, clean water, sanitation and nutrition.

Therefore, to reduce poverty means to improve and sustain the economic, social growth of the masses so as to enhance their living standard for national development.

\subsection{Indices of Poverty}

Certain indices are used to classify an individual community or state as being poor. Such conditions or indices are outlined and discussed here under.

- Low Consumption of Income Level: An individual, Community or a country is considered to be poor if the consumption of income level falls below some minimum level needed to meet the basic needs of life. Minimum level is otherwise referred to as poverty line. Poverty line vary in time, place and from country to country.

- Low-life Expectancy: Certain countries of the world especially those of Africa lack basic necessities that are expected of worthy living here on earth. Low life expectancy manifest in the form of massive illiteracy, parity in purchasing power., low Gross Domestic Product per capital, unemployment, hunger, disease, malnutrition, infant mortality. The United Nations Development Programme (UNDP) report (1997) ranked Nigeria to occupy the position of 146 out of 174 identified as poor countries. This is an indication that poverty is very high in the country.

- Lack of Basic essential Human Capabilities: Poverty ridden society is usually affected by lack of basic essential human capabilities which are needed to rise from the position of poverty to a sustained human development.

\subsection{Theoretical Foundation}

The paper employed political economy approach as the theoretical framework. Political economy theory has its roots from the classical works of Marx and Engels (1962) who derived his -intellectual stands from the works of great economists such as Smith (1937), Pye (1966) and Mill (1970). Political economy theory is concerned with the distribution of social wealth, class relations and conflicts as well as their impacts on the development of the society from one stage to another. Political economy approach tries to explain the social relations existing among people in the society in all the processes of production, exchange and consumption of goods and services.

Every society has a peculiar system of economic system anchored on property relations. Political economy approach gives credence to material conditions, particularly economic factors in all social lives. Without doubt,economic needs are the most fundamental needs of man, because he must eat before pursuing other things such as worship, culture, tourism, and other social things. Ake (2005:1-2) further posit that:

Once we understand what the material assets and constraints of a society are, how the society produces goods to meet its material needs, how the goods are distributed and what type of social relations arise from the organization of production, we have come a long way to understanding the culture of that society; its laws, its religious system, its political system and even its modes of thought. 
Political economy theory looks into the interconnection of phenomena, programmes and policies with the sole intention of discovering the class origin, character, composition and the logic of their existence and future. Thus, this approach is used in the analysis of problem of poverty in Nigeria, especially as the social relations emanating from productive forces create room for class differentiation in the society. While some categories of people in the society swim in affluence, others wallow in poverty.

\section{Methodology}

Survey was the research design adopted to elicit data for this study. A 20-item Questionnaire was the instrument used for measuring the research data. The population of study constitute Community Development Unions and Association in the 13 Local Government Areas of Ebonyi State. Simple random sampling technique was used in the selection of the population.

The disproportionate stratified sampling technique- one in which an equal number of cases are taken from each stratum regardless of how the stratum is represented in local government was used for distribution of a 20 -item questionnaire across the local governments. This resulted in the administration of 290 questionnaire items in the Local governments which were selected by simple random sampling technique.

The study used content and simple percentages for the purpose of analyzing data. Data presentation was done with aid of statistical tables which contain the level of performance.

\section{Causes of Poverty in Nigeria}

Poverty worldwide is an evil wind that blows no one any good. But then, does poverty occur naturally without any cause? This paper tries to identify certain factors that cause poverty in our contemporary societies. By and large, what cause poverty in Nigeria varies and are complex to explain. Jones (1986) did observe that the causes of poverty in any nation are associated more with the socio-political and economic settings of such a nation and not necessarily with the people. Obi, Nwachukwu and Obiora (2008), Burkey (1993) and Eneh (2011) enumerated causes of poverty, especially in Nigeria to include: low productivity, market imperfections, environmental degradation, lack of modernization tendencies, physical limitations, bureaucratic stiffing, dependency of third world countries, income inequalities, laziness, illiteracy, increased population, hunger, lack of industry, exploitation, lack of initiative, low productivity, lack of skills, economic underdevelopment, non implementation of policies and programmes, corruption, political instability, social conflict, weak governance, mismanagement, unemployment and ignorance.

A cursory look at the factors above, reveals that some are exogenously caused while others like illiteracy and laziness are endogenously oriented. The only factor that has speedily oiled and fuelled poverty is distribution of income. The distortion of income is not a problem among the poor but among the population (Bellow, Shehu and Madu, 2011). Essentially, Adawo (2010) argued that distribution of income could be viewed from two perspectives viz; the fiscal distribution of income and provision of both social and economic infrastructure. Imperatively, in Nigeria, the practice of relative wage income hypothesis, where jobs are evaluated on the basis of job content and wages are paid accordingly is largely not applicable, rather government incomes at all levels are shared among politicians, political cohorts and dubious contractors (Edoh, 2003). Paradoxically, the fact that infrastructures (good road network, health facilities, electricity and potable water) are not provided endemically spreads poverty (Barnes, 2010).

Looking at the African settings, Joseph (2006) pointed out that what contribute to poverty include: family size, low level of human capital, inaccessibility to cultivable land, lack of all weather roads, poor access to market and slow endowment of human capital. Other causes of poverty in Nigeria include: Poor health status of citizens, family structure (Polygamy) ignorance, economic crisis, culture and social values (Nkwede, 2010).

\section{Nigeria and Various Policies and Programmes on Poverty Reduction}

Nigerian as a nation since independence has been ravaged by poverty, but successive military and civil administrations have at various times initiated one policy/programme or the other to alleviate or reduce poverty among the citizens. This all important goal of poverty alleviation of the Nigerian government has over the years proved difficult as a result of certain factors such as: rapid population growth, slow economic growth, corruption, and mismanagement of resources, maladministration and poor policy implementation.

Eminue (2005) argues that poverty alleviation programmes in Nigeria are categorized into two types namely:

(A) Core poverty Alleviation programmes which aim at increasing access of the poor to micro-credit facilities and employment opportunities. Examples (i) Better life for Rural women (BLRW) (ii) Family support 
programme (FSP) (iii) Family economic Advancement programme (FEAP) (iv) National Directorate of Employment (NDE) (v) The People's Bank of Nigeria (vi) National Poverty Eradication Programme (NAPEP)

(B) Programme with Mandate for poverty Alleviation which are non-targeted programmes designed to provide various services for the purposes of enhancing productivity, income and welfare of the poorest segment of the society. Examples include:

(i) Green Revolution (ii) Operation Feed the Nation (OFN) (iii) Directorate for Food. Roads and Rural Infrastructure (DFRR1) (iv) Niger Delta Development Commission (NDDC). Former Oil Mineral Producing Areas Development Commission (OMPADEC) (v) Petroleum (Special) Trust Fund (PTF) (vi) Education Trust Fund (ETF) (vii) River Basin Development Authorities (viii) Community Banks (Now micro Finance Banks) (ix) Agricultural Development Projects (ADPs) (x) Nigerian Agricultural Cooperative and Rural Development Banks (xi) National Programme on Immunization (NP1) (xii) Expanded Programme on Immunization (EPI) (xiii) Nomadic Education Programme (xiv) Adult Non-formal Education Programme (xv) Programmes for the Disabled and Disadvantaged Groups.

All these programmes were designed by the government of Nigeria at various times for alleviation of poverty, yet the evidence of poverty in the country has remained very high and unchecked too. The implication of persistence of incidence of poverty is that it has defiled all alleviation policy options marshaled by the successive government of this country. Therefore, the present and future government of the country is faced with the difficult challenge of re-designing or modifying policies and programmes to fight poverty in all ramifications for sustainable socio-economic growth and development.

The source of concerned is the astronomical increase of poverty rate in Nigeria. Between 1980 to 1996 , poverty rate has risen from $27 \%$ to $66 \%$. By 1999 , over $70 \%$ of Nigerians lived in poverty with mere life expectancy of 54years, infant mortality at 77 per 1,000 births and maternal mortality at 704 per 100.000 live births. According to National Planning Commission (2004), other social indicators of poverty in Nigeria include:

(i) Rural house hold spends an average of 1.5 hours a day and walk for an average of one kilometer a day to collect water and fire wood.

(ii) More than $90 \%$ of the rural population depends on forests for their livelihood and domestic energy sources.

(iii) Only about $10 \%$ of the population has access to essential drugs.

(iv) Over five million adults out of 140 million Nigerian populations are estimated to be living with HIV/AIDS

(v) Among Nigerian children of five years of age, almost $30 \%$ of them are underweight.

(vi) Only about half of the population has access to safe drinking water. (40\% in rural areas, $80 \%$ in urban areas)

(vii) About $29 \%$ of the total population lives at risk from annual floods.

(viii) Only $17 \%$ of the children are fully immunized and almost $40 \%$ has never been vaccinated.

(ix) There are fewer than 30 physicians per 100,000 people (Nkwede, 2011).

\subsection{Ebonyi State and Level of Poverty}

Ebonyi State is one of the thirty six (36) States of the Federal Republic of Nigeria. The state was carved out of old Enugu and Abia States on $1^{\text {sl }}$ October, 1996 under the military administration of Late Gen. Sanni Abacha. Poverty in Ebonyi State at its creation was so pervasive that it was classified as the most poor state among the South East Zone. The federal office of statistics record shows that $52.6 \%$ of Ebonyi people are poor and that signs for social sectors development are not favourable, particularly for the poor. Even at present, evidence of poverty is still very high, despite the huge human potentials and natural resources endowed to the state (Nkwede, 2011).

In Ebonyi State, basic infrastructural facilities such as roads, health services, education, water supply, electricity, housing etc are lacking in most communities and where such amenities exist, they have virtually collapsed. Other signs of poverty among Ebonyians manifests in the malnourishment of vulnerable group (children and women), acute unemployment, child labour, hawking among the youth from rural areas where approximately seventy percent $(70 \%)$ of the population are living.

The United Nations Development programme UNDP Human Development Report (2002) for Enugu/Ebonyi, revealed that Ebonyi ranked very low on the human Development index (HDI) using a combined measurement of longevity (Physical Health), knowledge (Education) and income (Purchasing Power). According to the report, low life expectancy for males is estimated to be below 59.2 years and that of the females is 60.7 years. Mortality rate for children under five (5) years is 191 per 1000 life. One third 1/3 of the state's population resides in rural 
setting without safe water and good sanitation. Sources of drinking water are often from shallow and open wells, contaminated water from rivers and ponds. A good number of Ebonyi people are still illiterate and social amenities are lacking and industries are non existent. For instance, Ebonyi is one of the states in Nigeria without 132 KVA electric transformers needed for rapid industrialization.

The health sector in Ebonyi State is not measuring up in any way. Hospitals are not adequate and where there arc found, they are not properly equipped or without medical personnels such as doctors, nurses and hospital attendants. Resurgence of preventable diseases such as malaria, tuberculosis, sexually transmitted diseases (STD), HIV/AIDS, Guinea worm, diabetes mellitus etc are still very high.

In the area of education, although the state government introduced free and compulsory primary and secondary education, Ebonyi is still rated as educationally disadvantaged state in Nigeria. Ebonyi indigenes of school ages are still found in large numbers hawking, child labouring in many cities all over the country. Again, despite state government declaration of free and compulsory education, teaching and learning are still inadequate. Classroom blocks constructed by the missionaries and Nigerian government before and after the civil war are still in a state of dilapidation with blown off roofs and children are left to study under tree shades. Where buildings are found, the classrooms are not usually equipped with desks, even teachers teach without tables and chairs.

In Ebonyi State, road network is still very poor especially in the rural areas where over $70 \%$ of state populations who are predominantly farmers are residing. Poor road network in Ebonyi State has serious effects on evacuation of farm products and movement of people to and from the rural areas.

In all, the above situation clearly shows that Ebonyi State is one of the poorest states in Nigeria. Poverty, hunger, diseases, malnutrition, illiteracy, unemployment, lack of basic social amenities are still on the high side in the State. It was on this note that the Federal Ministry of Finance and the National Planning Commission selected Ebonyi State as one of the six(6) pilot states in Nigeria for Community Based poverty Reduction project (CPRP).

\subsection{The Ebonyi State Community Based Poverty Reduction Agency (EBCPRA).}

The Ebonyi State Community Based Poverty Reduction Agency (EBCPRA) was set up on $23^{\text {rd }}$ August. 2005 as an autonomous body charged with the task of reducing poverty in the state. EB-CPRA was established to function without undue interference or bureaucracy and with the mandate to improve on the socio-economic conditions of Ebonyi people, particularly the rural populace. The agency was to ensure that the rural population gets a fair share of at least $80 \%$ of government funding of micro projects.

By the design of the agency, communities should identify projects while EB-CPRA would select from the proposed projects by the benefiting communities through registered Community Development Associations. The Community Development Unions are usually composed of selected representatives to include the chairman, secretary, women representative (usually the treasurer), youth leader and the disabled as the case warrants.

EB-CPRA has its headquarters located at Abakaliki and unit offices at the Community Development Departments in the thirteen (13) local Government Areas of the state and other relevant line ministries.

\subsection{Functions of EB-CPRA}

With the skyrocketing level of poverty in Ebonyi, the state government put the Agency in place with the following functions.

(i) To support policies and utilize effective strategies for effectives implementation of projects in the benefiting communities for poverty reduction in Ebonyi State,

(ii) To disburse funds provided by donor agencies in support of poverty reduction in the state.

(iii) To appraise applications/projects received from beneficiary communities against eligibility criteria as spelt out in the operations manual so as to determine whether those projects need support, rejection or deferment,

(iv) To carry out public enlightment, advocacy, awareness and mobilization of communities toward poverty reduction,

(v) To render advisory services and technical assistance to communities, non-governmental organizations and community Based organizations on project designs, planning and management,

(vi) To carryout institutional and social needs assessment surveys, training, studies, evaluation and capacity building programme directed at improving the effectiveness and the impact of poverty reduction strategies in benefiting communities,

(vii) To supervise and monitor the implementation of poverty reduction projects in benefiting communities in liaison with the local government, NGOs and community Based organizations, 
(viii) To Liaise with the relevant ministries, local governments, donor agencies, research institutions and CBOs in the implementation of poverty reduction projects in the benefiting communities,

(ix) To ensure accountability, transparency and openness in all projects involving poverty reduction in the state,

(x) To appraise, finance and supervise projects designed, sponsored and implemented by the benefiting communities,

(xi) To work in line with the poverty Reduction programmes of the federal government, donor agencies, foreign government and bodies for harmonization and to avoid duplication of efforts,

(xii) To Liaise with the National Planning Commission to ensure that Ebonyi state benefits from other poverty alleviation programmes of the federal government and international organizations.

\subsection{Ebonyj State Community Based Poverty Reduction Agency (EB-CPRA) and Poverty Reduction in Ebonyi} State

Sequel to its establishment and the mandate to fashion out strategies to reduce poverty in our rural communities, the Ebonyi State Community Based Poverty Reduction Agency through the use of community based approach had in the past embarked on a number of projects which have direct or indirect impacts on the socio-economic lives of the population of citizens living below poverty line in the state. The agency has been involved in the construction of many micro projects ranging from provision of health centers, classroom blocks, road/bridges, bore-hoies drilling, rural electrification, market stalls to civic/skill acquisition centers.

In order to allow for full programme participation, the agency allows the benefiting communities to pay counterpart of just $10 \%$ of the cost of the project and to identify such projeet (s) by themselves. The agency physically monitored and supervised projects under their jurisdiction and evaluates their level of completion stage by stage. The agency's direct involvement and supervision of projects has led to completion of numerous projects on schedule and according to specifications. A summary of the agency's selected and executed projects as at 2008 across the state are shown in the tables below:

Table 1. Education Sector

\begin{tabular}{|c|c|c|c|c|c|}
\hline $\mathbf{S} / \mathbf{N}$ & Community/Ass. & L.G.A & Project/Baich No & $\begin{array}{c}\text { Cost of Project } \\
(\mathrm{N})\end{array}$ & Remarks \\
\hline 1. & Ndiagu Ode Dev. Union & Ohaukwu & $\begin{array}{l}\text { Pry. Sch. 6-classroom block } \\
\text { and VIP Toilet's } \\
\text { EB-PRA/B01/15/015 }\end{array}$ & $\$ 4,485,000$ & $\begin{array}{l}\text { Completed \& } \\
\text { Commissioned }\end{array}$ \\
\hline 2. & $\begin{array}{l}\text { Izubudo Age Grade } \\
\text { Ezeke, Amasiri }\end{array}$ & Afikpo North & $\begin{array}{l}\text { Sec. Sch; } 6 \text { - classroom block } \\
\text { and VIP toilets } \\
\text { EB-PRA/B02/20/040 }\end{array}$ & $¥ 4,700,000$ & $\begin{array}{l}\text { Completed \& } \\
\text { Commissioned }\end{array}$ \\
\hline 3. & $\begin{array}{l}\text { Ndiechi Amachi Dev. } \\
\text { Union }\end{array}$ & Abakaliki & $\begin{array}{l}\text { Sec. Sch; } 6 \text { - classroom block } \\
\text { and VIP toilets } \\
\text { EB-PRA/B05/11/091 }\end{array}$ & $\# 4,750,000$ & $\begin{array}{l}\text { Completed \& } \\
\text { Commissioned }\end{array}$ \\
\hline 4. & Umuezekoha Youths Ass. & Ezza North & $\begin{array}{l}\text { Sec. Sch; } 6 \text { - classroom block } \\
\text { and } \quad \text { VIP toilets } \\
\text { EB-CPRA/B06/04/I04 }\end{array}$ & $\$ 4,750,000$ & $\begin{array}{l}\text { Completed \& } \\
\text { Commissioned }\end{array}$ \\
\hline
\end{tabular}

Source: Ebonyi State Community Poverty Reduction Agency 2008

Table 2. Civic/Skill Acquisition Centre

\begin{tabular}{|c|c|c|c|c|c|}
\hline $\mathbf{S} / \mathbf{N}$ & Community/Ass & L.G.A & Project/Batch No & Cost of Project (N) & Remarks \\
\hline 1. & Edda Women's League & Afikpo South & $\begin{array}{l}\text { Skill Acquisition Centre } \\
\text { EB-CPRA/B02/1 7/037 }\end{array}$ & $¥ 3,000,000$ & $\begin{array}{l}\text { Completed \& } \\
\text { Commissioned }\end{array}$ \\
\hline 2. & $\begin{array}{l}\text { Ikeoha Welfare } \\
\text { Association }\end{array}$ & Izzi & $\begin{array}{l}\text { Civic/skills Acquisition centre } \\
\text { EB-PRA/B01G/12/012 }\end{array}$ & $\$ 5,000.000$ & $\begin{array}{l}\text { Completed \& } \\
\text { Commissioned }\end{array}$ \\
\hline 3. & $\begin{array}{l}\text { Agbataobi Nwanne } \\
\text { Progressive Union }\end{array}$ & Ebonyi & $\begin{array}{l}\text { Civic/skills acquisition centre } \\
\text { EBCPRA/BOIG/09/009 }\end{array}$ & $\mathrm{N} 4,100,000$ & $\begin{array}{l}\text { Completed \& } \\
\text { Commissioned }\end{array}$ \\
\hline
\end{tabular}

Source: Ebonyi State Community Poverty Reduction Agency (EB-CPRA) 2008 
Table 3. Market Development

\begin{tabular}{|c|c|c|c|c|c|}
\hline $\mathbf{S} / \mathbf{N}$ & Co mm unity /Ass. & L.G.A & Project/Balch No. & Cost of Project (N) & Remarks \\
\hline 1. & Akacze Ukwu Dev. Union & Ivo & $\begin{array}{l}7 \text { blocks of Market stalls } \\
\text { EB-CPRA/BO 1/02/002 }\end{array}$ & $\$ 5,000,000$ & $\begin{array}{l}\text { Completed \& } \\
\text { Commissioned }\end{array}$ \\
\hline 2. & $\begin{array}{l}\text { New Life Women } \\
\text { Association }\end{array}$ & Ez/a North & $\begin{array}{l}\text { Market stalls } \\
\text { EB-CPRA/B04/12/072 }\end{array}$ & $\$ 3,600,000$ & $\begin{array}{l}\text { Completed \& } \\
\text { Commissioned }\end{array}$ \\
\hline 3. & $\begin{array}{l}\text { Amike Izhia Dev. } \\
\text { Association }\end{array}$ & Ohaukwu & $\begin{array}{l}3 \text { blocks Market stalls } \\
\text { EB-CPRA/B02/I9/039 }\end{array}$ & $¥ 5,700,000$ & $\begin{array}{l}\text { Completed \& } \\
\text { Commissioned }\end{array}$ \\
\hline 4. & $\begin{array}{l}\text { Amachi Women } \\
\text { Association. }\end{array}$ & Abakaliki & $\begin{array}{l}\text { Market stalls } \\
\text { EB-CPRA/B04/ 15/075 }\end{array}$ & $¥ 3,570,000$ & $\begin{array}{l}\text { Completed \& } \\
\text { Commissioned }\end{array}$ \\
\hline
\end{tabular}

Source: EH-CPRA 2008

Table 4. Health Sector

\begin{tabular}{|c|c|c|c|c|c|}
\hline $\mathrm{S} / \mathbf{1 N}$ & Community /Ass & L.G.A & Project/Batch No & $\begin{array}{c}\text { Cost of Project } \\
(\mathrm{N})\end{array}$ & Remarks \\
\hline 1. & $\begin{array}{l}\text { Ishituma Progressive } \\
\text { Union }\end{array}$ & Ohaukwu & $\begin{array}{l}\text { Health Centre } \\
\text { EB-CPRA/BO 1/20/020 }\end{array}$ & $\mathrm{N} 4,750,000$ & $\begin{array}{l}\text { Completed \& } \\
\text { Commissioned }\end{array}$ \\
\hline 2. & $\begin{array}{l}\text { Inyimagu Ameke Dev. } \\
\text { Union }\end{array}$ & Ikwo & $\begin{array}{l}\text { Health Centre } \\
\text { EB-CPRA/B04/01/061 }\end{array}$ & $¥ 4,850,000$ & $\begin{array}{l}\text { Completed \& } \\
\text { Commissioned }\end{array}$ \\
\hline 3. & Ezza Inyimagu Dev. Ass. & Izzi & $\begin{array}{l}\text { Health Centre } \\
\text { EB-CPRA/B05/1 /096 }\end{array}$ & 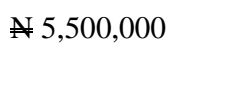 & $\begin{array}{l}\text { Completed \& } \\
\text { Commissioned }\end{array}$ \\
\hline 4. & $\begin{array}{l}\text { Otuchinyere Ugo Dev. } \\
\text { Union }\end{array}$ & Onicha & $\begin{array}{l}\text { Health Centre } \\
\text { EB-CPRA/BO /05/005 }\end{array}$ & $¥ 4,700,000$ & $\begin{array}{c}\text { Completed \& } \\
\text { Commissioned }\end{array}$ \\
\hline
\end{tabular}

Source: EB-CP8A 2008

Table 5. Road and Bridges

\begin{tabular}{|c|c|c|c|c|c|}
\hline $\mathbf{S} / \mathbf{N}$ & Community/ Ass & L.G.A & Project/Batch No & Cost of Project ( & Remarks \\
\hline 1. & Umunnabuike Dev. Ass. & Ivo & $\begin{array}{l}\text { Rehabilitation of } 9.6 \mathrm{~km} \text { Road } \\
\& \text { Construction of } 15 \text { culverts } \\
\text { EB-PRA/B01/03/003 }\end{array}$ & $\$ 4,750,000$ & $\begin{array}{l}\text { Completed \& } \\
\text { Commissioned }\end{array}$ \\
\hline 2. & $\begin{array}{l}\text { Aguebele Progressive } \\
\text { Union }\end{array}$ & Ohaukwu & $\begin{array}{l}\text { Construction of a bridge } \\
\text { EB-CPRA/B03/12/052 } \\
\text { Bridge \& Culverts } \\
\text { construction }\end{array}$ & $\begin{array}{l}¥ 4,9 \mathrm{I} 3,640 \\
¥ 2,750,000\end{array}$ & $\begin{array}{l}\text { Completed \& } \\
\text { Commissioned } \\
\text { Completed \& } \\
\text { Commissioned }\end{array}$ \\
\hline 3. & Iziola Dev. Association & Ebonyi & EB-CPRA/B05/01/081 & & \\
\hline 4. & $\begin{array}{l}\text { Umunna Future Hope. } \\
\text { Ass. }\end{array}$ & Afikpo North & $\begin{array}{l}\text { Construction of } 3.6 \mathrm{~km} \text { Rural } \\
\text { road \& } 3 \text { bridge } \\
\text { EB-CPRA/B03/02/042 }\end{array}$ & $\$ 4,885,200$ & $\begin{array}{l}\text { Completed \& } \\
\text { Commissioned }\end{array}$ \\
\hline
\end{tabular}

Source: ER-CPRA 2008

Table 6. Rural Electrification Project

\begin{tabular}{|c|c|c|c|c|c|}
\hline $\mathbf{S} / \mathbf{N}$ & Community/Ass & L.G.A & Project/Batch No & Cost of Project ( $(\mathbb{A})$ & Remarks \\
\hline 1. & $\begin{array}{l}\text { Ezza Inyimagu Comm. } \\
\text { Dev Union }\end{array}$ & Izzi & $\begin{array}{l}\text { Extension of Rural } \\
\text { Electrification } \\
\text { EB-CPRA/BO 1/06/006 }\end{array}$ & $\# 5,250,000$ & $\begin{array}{l}\text { Completed \& } \\
\text { Commissioned }\end{array}$ \\
\hline 2. & Ebia Unuhu Dev. Forum & Abakaliki & $\begin{array}{l}\text { Rural Electrification } \\
\text { EB-CPRA/B05/09/089 }\end{array}$ & $¥ 5.000,000$ & $\begin{array}{l}\text { Completed \& } \\
\text { Commissioned }\end{array}$ \\
\hline 3. & $\begin{array}{l}\text { Ogwawo Area Dev. } \\
\text { Initiative }\end{array}$ & Ohaukwu & $\begin{array}{l}\text { Rural Electrification } \\
\text { EB-CPRA/B03/ 10/050 }\end{array}$ & $¥ 4,932,593$ & $\begin{array}{l}\text { Completed \& } \\
\text { Commissioned }\end{array}$ \\
\hline
\end{tabular}

Source: EB-CPRA 200S 
Table 7. Water Projects

\begin{tabular}{|c|c|c|c|c|c|}
\hline $\mathbf{S} / \mathbf{N}$ & Community/Ass & L.G.A & Project/Batch No & $\begin{array}{c}\text { Cost of Project } \\
(\mathrm{A})\end{array}$ & Remarks \\
\hline 1. & $\begin{array}{l}\text { Oferekpe Ezza Inyimagu } \\
\text { Women Welfare Ass. }\end{array}$ & Izzi & $\begin{array}{l}6 \text { Boreholes one with overhead } \\
\text { tank } \\
\text { EB-CPRA/B02/18/038 }\end{array}$ & 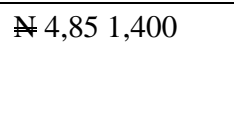 & $\begin{array}{l}\text { Completed \& } \\
\text { Commissioned }\end{array}$ \\
\hline 2. & $\begin{array}{l}\text { Uvuewa/Umuokpala } \\
\text { progressive union }\end{array}$ & Ohaozara & $\begin{array}{l}4 \text { overhead tank, plant house \& } \\
3 \text { Boreholes } \\
\text { EB-CPRA/B05/19/099 }\end{array}$ & $\$ 4,000,000$ & $\begin{array}{l}\text { Completed \& } \\
\text { Commissioned }\end{array}$ \\
\hline 3. & $\begin{array}{l}\text { Biledeba youths progressive } \\
\text { union }\end{array}$ & Ishielu & $\begin{array}{l}3 \text { Boreholes } \\
\text { EB-CPRA/BOIG/10/010 }\end{array}$ & $\# 1,950,000$ & $\begin{array}{l}\text { Completed \& } \\
\text { Commissioned }\end{array}$ \\
\hline 4. & Ebunwana Edda Comm. & Afikpo South & $\begin{array}{l}\text { Water treatment plant } \\
\text { EB-CPRA/B04/03/063 }\end{array}$ & $\Downarrow 4,900,000$ & $\begin{array}{l}\text { Completed \& } \\
\text { Commissioned }\end{array}$ \\
\hline
\end{tabular}

Source: EB-CPRA 2008.

\section{Constraints to Poverty Alleviation/Reduction Programmes in Nigeria}

Successive administrations in Nigeria have initiated several policies and programmes aimed at alleviating poverty in the country, yet none of them could be said to have had significant positive effect. Certain factors appear to have been identified as hindrances to government efforts in reducing the high incidence of poverty in Nigeria. Such problems include inter alia;

(i) Lack of efficient coordination (ii) Lack of comprehensive policy framework (iii) political interference (iv) political instability (v) poor programme funding (vi) overlapping of functions of implementation agencies (vii) wrong target of the beneficiaries (viii) corruption and mismanagement (ix) inability to sustain the programme or projects (x) lack of proper focus (ix) lack of effective monitoring, costing and evaluation of programmes.

Based on the above assertions, it is very clear that government of Nigeria has not really tackled the root cause of poverty in the country through her poverty policy initiatives. As a result, indices of poverty are still very high in the country.

\section{Conclusion/Recommendations}

Poverty is a serious issue all over the world. It is one of the greatest phenomenon that pose dangerous challenge to mankind in both developed and emerging nations. Evidence abound that danger signals of poverty are more prevalent in the third world nations of Africa, Latin America and the Caribbean. In Nigeria to be precise, symptoms of poverty are so high that they have defiled all alleviation measures initiated by the successive governments in her development programmes. But despites government laudable policies and programmes over the years to address the perennial problem of poverty in Nigeria, poverty is still rearing its ugly head in the country. Against the back drop of persistent occurrence of poverty in the country, this paper makes the following recommendations as panacea for poverty reduction or alleviation in Nigeria.

All government policies and programmes directed at alleviating poverty should be comprehensive enough so as to adequately articulate the most efficient and effective ways by which various indices of poverty can be holistically addressed.

- Contrary to wrong target of the poor people, the government and all concerned with the task of poverty reduction should ensure proper identification of the real poor ones for the purposes of ascertaining and compelling them to participate in poverty alleviation programmes or activities such as skill acquisition, micro-credit finance, self employment, special education, scholarship training etc.

- Government and concerned bodies on poverty reduction should from time to time organise workshops, seminars, conferences, public lectures and symposia to create awareness and educate the general public, especially the rural dwellers on poverty alleviation issues.

- Moreso, good governance and transparency should form the hallmark so as to achieve pragmatic strategies for achieving positive and cost-effective result in the implementation of poverty alleviation agenda.

- The supervising agencies of poverty alleviation activities should ensure proper coordination and monitoring of poverty alleviation projects in the country. Proper supervision will actually reduce wastages, duplication of efforts and dissipation of energies and make all poverty programmes to remain focused and realistic to achieve targets. 
- Government and donor organizations concerned with poverty alleviation programmes should increase funding of all line ministries and agencies involved in the poverty alleviation programme.

- Finally, the issue of rural-urban migration should be properly checked and managed to avoid urban congestion and chronic unemployment situation.

\section{References}

Ake, C. (2005). A Political Economy of Africa. London: Longman Group Ltd.

Adawo, M. A. (2010). Poverty in Uyo: Characteristics, Causes and Consequences. Journal of Economic Theory, 4.

African Development Bank. (1998). African Development Report Human Capital Development, Oxford University Press.

Barnes, A. (2010). Poverty Eradication, Millennium Development Goals and Sustainable Development in Nigeria. Journal of Sustainable Development, 3(4).

Bello, M. F., Shehu, J. S., \& Madu, A. Y. (2011). Combating Poverty in Nigeria for Sustainable Development: A Necessary Agenda. International Journal of Social Sciences and Humanities Review, 2(3).

Burkey, S. (1993). People First, A Guide to Self-reliance, Participatory Rural Development, London: Zed Books Ltd.

Chamber, F (1995). Poverty and Livelihood: Whose Reality Really counts. A Policy Paper Commissioned by UNDP for the World Summit for Social Development.

Dike, V. E. (2002). "Poverty in Nigeria", The Daily Independent, October 6 P.11.

Edoh, T. (2003). Poverty and the Survival of Democracy in Nigeria. Nigerian Journal of Political Administrative Studies, 1(4).

Eminue, O. E. (2005). Public Policy Analysis and Decision Making, Lagos: Concept Publications Ltd.

Eneh, O. (2011). Nigeria's Vision 20:20:20 - Issues, Challenges and Implication for Development Management. Asian Journal Development, 2.

Ezeanyika, S. E. (2004). Empirical Studies on Poverty Alleviation in Nigeria, Development Studies Research Group (DESREG) Lecture Series No 9.

Igbuzor, O. (2006). Bulletin Action Aid International Nigeria, No. 2 January-June.

Jones, L. (1986). "Societal Influence on Poverty". In Jogindar, S and Howie M. R (eds) Dimensions of Rural Poverty in the South, Florida: CCDRESTA Press.

Joseph, K. O. (2006). Poverty Alleviation Strategies and the Challenges of Governance in Nigeria: The way forward from legion of failed Policies. International Journal of Social and Policy Issues, 4(1).

Landis, P. H. (1980). Sociology, Massachusset: Ginn and Company.

Marx, K., \& Engels, F. (1962). The German Ideology, Moscow: Progress Publishers.

National Planning Commission. (2004). National Economic Empowerment and Development Strategy (NEEDS), Abuja: National Planning Commission.

Nkwede, J. O. (2010). Implications of Working Class Poverty on Sustainable Democracy in Developing Countries: Nigeria in Perspectives. International Journal of Social Sciences and Humanities Review, 1(2).

Nkwede, J. O. (2011). International Development Association and Community Development in Nigeria: A study of World Bank Assisted Community Based Poverty Reduction programme in selected communities of Ebonti State, an unpublished Ph.D Thesis, Department of Political Science, Ebonyi State University, Abakaliki.

Obadan, M. I (1996). Poverty in Nigeria: Characteristics, Alleviation Strategies and Programmes. NCEMA Policy Analysis Series, 2(2).

Obedan, J. J. (2006). Impact of Government's Poverty Reduction Programmes on some soci-economic variables: Evidence from Nigeria. International Journal of Social and Policy Issues, $4(1 \& 2)$.

Obi, E. A., Nwachukwu, L. C., \& Obiora, A. C. (2008). Public Policy Analysis and Decision Making. Onitsha: Book Point Educational Limited.

Osagie, E. (2007). The New Nigerian Economy from Poverty to Prosperity, Benin-City: AFBSN Publishers. 
Pye, L. (1966). Aspects of Political Development, Boston: Little Brown and Co.

Ravalillion, M., \& Chon, C. (2004). The Global Poverty Monitoring Database, Washington DC: World Bank.

Smith, A. (1937). The Wealth of Nations, New York: Random House Inc.

Todaro, M. P. (1992). Economics for a Development World: An Introduction to Principles, Problems and Policies for Development ( ${ }^{\text {rd }}$ ed), Longman Group, 326 P.

United Nations Development Programme. (1997). Nigerian Human Development Report, New York: United Nations.

World Bank. (1992). Poverty Reduction Hank Book. Washington DC USA.

World Bank. (1999). Nigeria Development Prospects. Washington D. C. The World Bank.

\section{(cc) $\overline{E Y}$}

This work is licensed under a Creative Commons Attribution 3.0 License. 